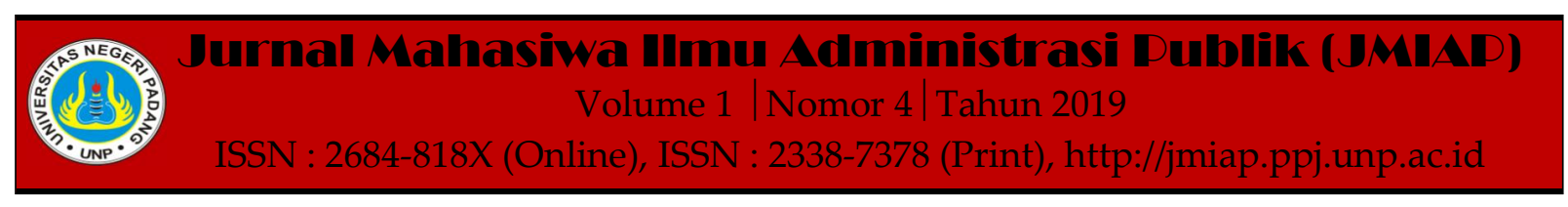

\title{
EFEKTIVITAS BALAI BESAR PENGAWAS OBAT DAN MAKANAN TERHADAP PENERTIBAN PELAKU USAHA KOSMETIK ILEGAL DI KOTA PADANG
}

\author{
Aynainil Mardiyahi(a), Aldri Frinaldi ${ }^{2(b)}$ \\ ${ }^{1}$ Jurusan Ilmu Administrasi Negara, Universitas Negeri Padang \\ ${ }^{2}$ Jurusan Ilmu Administrasi Negara, Universitas Negeri Padang \\ a)aynadiyah6104@gmail.com, ${ }^{\text {b) }}$ aldri@fis.unp.ac.id
}

\begin{abstract}
The higher the cosmetic needs, the easier the cosmetic circulation can be found. The purpose of this study was to find out how the effectiveness of Balai Besar Pengawas Obat dan Makanan on the control of cosmetic businesses in the city of Padang. Control is done to increase legal awareness of business actors and social control. The results of this study indicate that, first, there has not been a growing adherence of business actors to existing laws, so that illegal cosmetics are still marketed. Even though guidance or socialization has been carried out, but that is not enough to raise awareness of business actors on existing laws. Second, how social control is carried out by Balai Besar Pengawas Obat dan Makanan on business so that illegal cosmetics circulation has not reached its goals and objectives, due to socialization which has not been carried out thoroughly and because of legal sanctions that have not been firmly implemented.
\end{abstract}

Keywords : Effectiveness, Control, Illegal

Corresponding author. Email.aynadiyah6104@gmail.com,aldri@fis.unp.ac.id

How to cite this article. Mardiyah. A \& Frinaldi. A. (2019). Efektivitas Balai Besar Pengawas Obat dan Makanan terhadap Penertiban Pelaku Usaha Kosmetik Ilegal di Kota Padang. Jurnal Mahasiwa Ilmu Administrasi Publik (JMIAP) Jurusan Ilmu Administrasi Negara Fakultas Ilmu Sosial Universitas Negeri Padang, Volume 1 (4), Hal. 124-135.

http://jmiap.ppj.unp.ac.id

ISSN : 2684-818X (Online), ISSN : 2338-7378 (Print)

Copyright $\odot 2019$. Published by Pusat Kajian-Pemberdayaan dan Pelayanan Masyarakat (PK-P2M) FIS UNP Padang 


\section{PENDAHULUAN}

Obat, makanan, dan kosmetik merupakan kebutuhan masyarakat yang harus dilindungi. Semakin tinggi kebutuhan terhadap barang - barang tersebut, semakin mudah pula dijumpai peredarannya di lingkungan sekitar. Di Indonesia sendiri sudah banyak beredar obat, makanan dan kosmetik dengan berbagai merek. Mulai dari merek local, merek luar negeri, atau produk buatan rumah atau yang kita kenal dengan Hommade. Dengan bantuan ilmu pengetahuan ataupun ilmu teknologi barang - barang kebutuhan seperti obat, makanan dan kosmetik dapat diproduksi dengan skala besar dan menyebar dengan cepat keseluruh wilayah di dalam Negara maupun antar Negara.

Salah satu barang kebutuhan yang paling diminati dan mudah ditemui adalah kosmetik. Dalam Pasal 1 angka 1 Peraturan Menteri Kesehatan Republik Indonesia Nomor 1176/MenkKes/PER/VIII/2010 tentang Notifikasi Kosmetika, yang dimaksud dengan kosmetik adalah bahan atau sesuatu yang berfungsi untuk memepercatik atau mengubah penampilan yang digunakan pada tubuh khusunya pada wajah manusia.

Kosmetik merupakan hal yang lazim dipakai untuk perawatan atau untuk meningkatkan kecantikan khususnya untuk para perempuan. Untuk itu para wanita berlomba - lomba untuk mencari kosmetik yang dapat membuat wajah mereka lebih baik, terawat dan juga untuk mendapatkan kulit wajah yang lebih putih. Dan para produsen kosmetik perawatan wajah dan kecantikan pun banyak ditemui. Mereka menjual berbagai macam merek kosmetik, ada yang berasal dari luar negeri, local, ataupun buatan sendiri dengan harga yang berbagai macam pula. Mulai dari produk kosmetik mahal sampai yang murah.

Dalam UU Nomor 36 tahun 2009 Pasal 106 Tentang Kesehatan menjelaskan bahwa sediaan farmasi dan alat kesehatan hanya dapat diedarkan setelah mendapat izin edar, yang termasuk dalam sediaan farmasi adalah obat, bahan obat, obat tradisional dan kosmetika. Sebagai lembaga yang bertugas untuk pengawasan terhadap obat dan makanan di lingkungan masyarakat, Badan Pengawas Obat dan Makanan bertugas untuk melindungi masyarakat dari bahaya beredarnya kosmetik ilegal dan berbahaya. Dalam Peraturan Presiden Nomor 80 Tahun 2017, BPOM mempunyai tugas menyelenggarakan tugas pemerintahan di bidang pengawasan Obat dan Makanan sesuai dengan ketentuan peraturan perundang-undangan, yang termasuk dalam obat dan makanan terdiri atas obat, bahan obat, narkotika, psikotropika, prekursor, zat adiktif, obat tradisional, suplemen kesehatan, kosmetik, dan pangan olahan.

Sebagai tindak lanjut dari tugas Badan Pengawas Obat dan Makanan, maka telah ditetapkan Unit Pelaksana Teknis di Lingkungan Badan Pengawas Obat dan Makanan. Unit Pelaksana Teknis adalah satuan organisasi yang bersifat mandiri yang melaksanakan tugas teknis dari organisasi induknya. Dalam Peraturan Kepala Badan Pengawas Obat dan Makanan Nomor 14 Tahun 2014 yang telah diubah dengan Peraturan Badan Pengawas Obat dan Makanan Nomor 12 Tahun 2018 tentang Organisasi dan Tata Kerja Unit Pelaksana Teknis di Lingkungan Badan Pengawas Obat dan Makanan menjelaskan bahwa Unit Pelaksana Teknis di lingkungan Badan Pengawas Obat dan Makanan yang selanjutnya disingkat UPT BPOM adalah satuan kerja yang bersifat mandiri yang melaksanakan tugas teknis penunjang tertentu di bidang pengawasan obat dan makanan.

Salah satu UPT BPOM yang berada di Sumatera Barat adalah Balai Besar POM yang berlokasi di Padang, berfungsi untuk mengawasi peredaran kosmetik ilegal dan menertibkan para pelaku usaha yang masih memperdagangkannya. Berikut adalah jumlah kosmetik ilegal yang telah 
Aynainil Mardiyah, Aldri Frinaldi I Efektivitas Balai Besar Pengawas Obat dan Makanan terhadap Penertiban Pelaku Usaha Kosmetik Ilegal di Kota Padang

diamankan oleh Balai Besar POM di Padang tahun 2016 - 2018:

Tabel 1. Jumlah Kosmetik Ilegal yang disita Balai Besar POM Padang Pada Tahun 2016-2018

\begin{tabular}{cccc}
\hline No & Tahun & $\begin{array}{c}\text { Jenis } \\
\text { Kosmetik }\end{array}$ & Satuan \\
\hline 1 & 2016 & 355 & 5.800 \\
\hline 2 & 2017 & 127 & 2.789 \\
\hline 3 & 2018 & 731 & 11.720 \\
\hline Total & - & 1.213 & 20.309 \\
\hline \multicolumn{4}{c}{ Sumber: BBPOM Padang (2019) }
\end{tabular}

Dari data diatas dapat diketahui bahwa terdapatnya peningkatan terhadap temuan kosmetik ilegal di Kota Padang. Pengawasan dan penertiban merupakan faktor yang penting untuk dilakukan supaya mengurangi ataupun benar - benar menghabisi peredaran kosmetik tersebut, sehingga terciptanya lingkungan yang aman bagi masyarakat untuk memilih dan membeli kosmetik yang aman untuk dikonsumsi.

Kosmetik ilegal masih beredar dikarenakan masyarakat masih memiliki minat dan masih mengkonsumsi kosmetik tersebut, sehingga pelaku usaha pun masih memperdagangkannya. Balai Besar POM sebagai lembaga yang mengawasi peredaran kosmetik ilegal ini berupaya untuk menertibkan para pelaku usaha yang menyimpang dengan masih memperdagangkan kosmetik ilegal ini. Dalam UU Nomor 36 tahun 2009 Tentang Kesehatan menjelaskan bahwa barang siapa yang kedapatan memproduksi atau mengedarkan kosmetik ilegal mendapatkan hukuman pidana penjara maksimal 15 tahun atau membayar denda sebesar 1,5 milyar rupiah. Dan Pasal 2 Peraturan Kepala Badan Pengawas Obat dan Makanan Republik Indonesia Nomor
HK.03.1.23.12.11.10052 Tahun 2011 Tentang Pengawasan Produksi dan Perederan Kosmetika menjelaskan bahwa barang siapa yang masih mengedarkan kosmetik ilegal dan berbahaya akan dikenakan sanksi administratif berupa peringatan tertulis, larangan mengedarkan kosmetik untuk sementara, penarikan kosmetik tanpa izin edar, pemusnahan kosmetik, pembatalan notifikasi, dan penghentian sementara kegiatan produksi.

Dengan adanya sanksi hukum tersebut diharapkan para pelaku usaha menjadi sadar dan memiliki kepatuhan terhadap hukum yang ada. Namun yang terjadi adalah masih banyaknya pelaku usaha yang memperdagangkan kosmetik ilegal ini, dibuktikan dengan masih mudahnya ditemukan kosmetik tanpa izin edar dari BPOM beredar di Padang. Untuk itu dalam penelitian ini, peneliti akan membahas mengenai Efektivitas Balai Besar Pengawas Obat dan Makanan terhadap Penertiban Pelaku Usaha Kosmetik Ilegal di Kota Padang.

\section{TINJAUAN PUSTAKA Konsep Efektivitas}

Efektivitas merupakan sesuatu hal yang dapat menyatakan bahwa perencanaan maupun usaha yang dilakukan oleh organisasi dapat sejalan dengan tujuan yang diharapkan. Organisasi dapat dikatakan efektif apabila struktur kekuasaan, pola hubungan kekuasaan, cara pengawasan, kinerja pegawai dan produktivitas berjalan dengan baik disuatu organisasi. Efektifnya suatu perencenaan atau strategi yang dilakukan oleh organisasi diharapkan tercapainya keberhasilan. Dengan kata lain output diharapkan akan sesuai dengan yang dicapai (Witya \& Frinaldi, 2019).

Menurut Duncan (Steers, 1985) dimana terdapat tiga indikator untuk mengukur tingkat efektivitas, yaitu : 
1) Pencapaian Tujuan

Pencapaian tujuan dapat dilihat sebagai suatu proses. Untuk itu supaya tercapainya tujuan akhir, diperlukan cara - cara atau proses yang baik dan sesuai. Pencapaian tujuan terdiri dari kurun waktu, pencapaian sasaran dan target yang telah di tentukan. Organisasi dikatakan efektif apabila tujuan atau sasaran yang ingin mereka capai dapat terlaksana dengan baik.

\section{2) Integrasi}

Integrasi yaitu pengukuran terhadap tingkat kemampuan suatu organisasi untuk mengadakan sosialisasi ataupun komunikasi dengan berbagai macam organisasi lainnya.

\section{3) Adaptasi}

Adaptasi merupakan kemampuan manajemen untuk menyesuaikan diri dengan lingkungannya. Batasan dari pengertian adaptasi dapat diukur dari bagaimana organisasi melakukan perubahan terhadap situasi lingkungan yang berubah dan proses mengatasi halanganhalangan dari lingkungan tersebut.

\section{Konsep Penertiban}

Dalam Kamus Besar Bahasa Indonesia penertiban berasal dari kata tertib, yang berarti proses, cara atau perbuatan menertibkan. Menurut Aldri (2019) tertib mencerminkan suatu sikap disiplin yang tinggi, konsisten, teratur serta efisien dan dapat menimbulkan kenyamanan. Untuk menciptakan kenyamanan dan kesejahteraan rakyat organisasi pemerintah harus turun aktif dalam bidang kehidupan masyarakat, khusnya sosial dan ekonomi (Frinaldi, 2017). Pada Peraturan Pemerintah Nomor 32 tahun 2004 tentang pedoman polisi pamong praja, penertiban adalah tindakan untuk menciptakan kesadaran atau ketaatan warga masyarakat supaya tidak melanggar ketentraman dan ketertiban umum serta Peraturan Daerah dan Keputusan Kepala Daerah.

Dalam penelitian ini, peneliti juga memakai variabel penertiban, yang mana menurut Soekanto (2012) dengan

dilakukannya penertiban dapat meningkatkan :

\section{1) Kesadaran Hukum}

Untuk dapat menaati suatu peraturan hukum yang telah dibuat diperlukannya kesadaran hukum. Perasaan hukum dan keyakinan hukum seseorang di masyarakat, merupakan akar dari kesadaran hukum masyarakat. Kesadaran hukum masyarakat yaitu satuan terbanyak dari kesadarankesadaran hukum individu mengenai suatu hal yang terjadi. Kesadaran hukum individu dapat diukur dari sebarapa patuh dan mengerti mereka terhadap peraturan perundang-undangan yang berlaku.

\section{2) Pengendalian Sosial}

Pengendalian sosial mencakup segala proses, baik yang direncanakan, bersifat mendidik, atau bahkan mengajak warga masyarakat agar patuh terhadap peraturan peraturan yang berlaku. Suatu proses pengendalian sosial dapat dilaksanakan dengan berbagai cara tanpa kekerasan dan paksaan. Cara pengendalian sosial yang tepat tergantung pada faktor terhadap siapa pengendalian sosial tersebut dilakukan dan di dalam situasi yang bagaimana.

\section{Konsep Kendala}

Dalam Kamus Besar Bahasa Indonesia pengertian kendala adalah halangan, rintangan, ataupun gendala. Cox dan Schelier (Larasati \& Haksama, 2016) mengatakan bahwa Theory Of Constraints juga dikenal dengan TOC merupakan sebuah filosofi manajemen yang dikembangkan oleh Dr. Eliyahu M. Dolratt sejak tahun 1980-an. Theory Of Constraints didefinisikan sebagai suatu pendekatan ke arah peningkatan proses yang berfokus pada elemen- elemen yang membatasi kinerja dalam peningkatan output.

Menurut Hansen dan Mowen (Larasati \& Haksama, 2016) kendala terbagi atas, sebagai berikut : 
a) Kendala Internal. Kendala internal adalah factor-faktor yang membatasi organisasi dan sistem yang berasal dari dalam organisasi tersebut.

b) Kendala Eksternal. Kendala eksternal adalah factor-faktor yang membatasi organisasi yang berasal dari luar organisasi.

\section{Konsep Upaya}

Upaya menurut kamus besar bahasa Indonesia (KBBI) diartikan sebagai usaha kegiatan yang mengarahkan tenaga, pikiran untuk mencapai suatu tujuan. Upaya juga berarti usaha, akal, ikhtiar untuk mencapai suatu maksud, memecahkan persoalan mencari jalan keluar. Menurut Nawawi (Nawawi, 2010) upaya terbagi atas :

1) Pre-emtif. Upaya pre-emtif yaitu usaha-usaha awal yang dilakukan untuk mencegah terjadinya pelanggaran. Upaya yang dilakukan secara pre-emtif adalah menancapkan nilai - nilai begitu juga norma-norma yang baik supaya dapat meresap dalam diri sesorang.

2) Preventif. Upaya-upaya preventif adalah lanjutan dari upaya pre-emtif yang masih dalam kategori pencegahan sebelum terjadinya pelanggaran. Contoh usaha yang dilakukan secara preventif misalnya dengan melakukan inspeksi ataupun razia ke tempat-tempat yang dianggap rawan untuk terjadinya pelanggaran.

3) Represif. Usaha yang dapat dilakukan jika sudah terjadi tindak pidana yang tindakannnya yaitu penegakan hukum (law enforcement) dengan menjatuhkan hukuman.

\section{METODE PENELITIAN}

Dalam penelitian ini peneliti menggunakan pendekatan kualitatif dengan metode deskriptif. Lokasi penelitian di Balai Besar Pengawas Obat dan Makanan Padang, Dinas Kesehatan Kota Padang, Dinas Perindustrian dan Perdagangan Provinsi Sumatera Barat dan Polda Sumbar.
Data yang digunakan dalam penelitian ini merupakan data primer dan data sekunder. Pengumpulan data yang dilakukan dengan cara wawancara, observasi dan dokumentasi, dan uji keabsahan data dengan cara menggunakan teknik triangulasi sumber. Sedangkan untuk teknik analisis data dilakukan dengan cara reduksi data, penyajian data dan menarik kesimpulan.

\section{HASIL DAN PEMBAHASAN}

\section{Efektivitas Balai Besar Pengawas Obat dan Makanan terhadap Penertiban Pelaku Usaha Kosmetik Ilegal di Kota Padang}

Kosmetik ilegal adalah bahan atau sediaan bahan atau sesuatu yang dapat merubah penampilan namun tidak sah karena tidak memiliki izin edar dari BPOM dan tidak memenuhi persyaratan mutu serta dapat merugikan masyarakat. Kosmetik ilegal masih beredar dikarenakan masyarakat masih memiliki minat dan masih mengkonsumsi kosmetik tersebut, sehingga pelaku usaha pun masih memperdagangkannya. Balai Besar POM sebagai lembaga yang mengawasi peredaran kosmetik ilegal ini berupaya untuk menertibkan para pelaku usaha yang menyimpang dengan masih memperdagangkan kosmetik ilegal ini.

Dalam UU Nomor 36 tahun 2009 Tentang Kesehatan menjelaskan bahwa barang siapa yang kedapatan memproduksi atau mengedarkan kosmetik ilegal mendapatkan hukuman pidana penjara maksimal 15 tahun atau membayar denda sebesar 1,5 milyar rupiah. Dan Pasal 2 Peraturan Kepala Badan Pengawas Obat dan Makanan Republik Indonesia Nomor HK.03.1.23.12.11.10052 Tahun 2011 Tentang Pengawasan Produksi dan Perederan Kosmetika menjelaskan bahwa barang siapa yang masih mengedarkan kosmetik ilegal akan dikenakan sanksi administratif berupa peringatan tertulis, larangan mengedarkan kosmetik untuk sementara, penarikan kosmetik tanpa izin 
edar, pemusnahan kosmetik, pembatalan notifikasi, dan penghentian sementara kegiatan produksi. Untuk mengukur ke efektivitas Balai Besar Pengawas Obat dan makanan, dapat dilihat dari tiga aspek, yaitu sebagai berikut :

\section{1) Pencapaian tujuan}

Tujuan dari penertiban terhadap pelaku usaha kosmetik adalah untuk menertibkan pelaku usaha yang melanggara dan yang menyimpang dengan masih memperdagangkan kosmetik ilegal, untuk menumbuhkan kesadaran dan kepatuhan pelaku usaha terhadap hukum yang berlaku agar dapat terlindungnya masyarakat dari bahayanya peredaran kosmetik ilegal ini.

Balai Besar POM sudah berupaya se optimal mungkin dalam mengurangi peredaran kosmetik ilegal ini, dengan turun ke lapangan, ke tempat - tempat distribusi kosmetik, melakukan sosialisasi agar tumbuhnya kesadaran terhadap bahayanya kosmetik ilegal ini dan tumbuhnya kepatuhan terhadap peraturan hukum yang ada.

Namun karena masih kurangnya kepedulian masyarakat dan masih adanya minat masyarakat terhadap barang tersebut, pelaku usaha pun masih belum berhenti untuk memperdagangkannya. Sehingga tujuan Balai Besar Pengawas Obat dan Makanan untuk menghabisi peredaran kosmetik ilegal ini di masyarakat belum sepenuhnya tercapai.

\section{2) Integrasi}

Pada penelitian ini pengertian integrasi adalah tolak ukur yang digunakan terhadap tingkat kemampuan aparatur dalam mengadakan sosialisasi kepada masyarakat untuk mencapai efektivitas pengawasan dan penertiban Balai Besar Pengawas Obat dan Makanan terhadap kosmetik ilegal dan berbahaya di Padang. Untuk mengatasi peredaran kosmetik ilegal di masyarakat diperlukan sosialisasi dan komunikasi yang terus - menerus dan menyeluruh di masyarakat guna untuk meningkatkan pengetahuan mereka dan kesadaran mereka mengenai bahaya nya kosmetik ilegal tersebut.

Oleh karena itu Balai Besar Pengawas Obat dan Makanan dalam meningkatkan pengetahuan masyarakat tentang bahayanya kosmetik ilegal melalui sosialisasi yang dinamai dengan KIE (Komunikasi Informasi dan Edukasi). KIE (Komunikasi Informasi dan Edukasi) adalah suatu kegiatan sosialisasi yang dilakukan Balai Besar POM dalam bentuk penyebaran informasi mengenai bahaya nya produk produk ilegal, cara mengetahui bagaimana itu bentuk produk ilegal dan apa saja yang harus dilakukan masyarakat untuk menghindari produk ilegal tersebut yang mana gunanya untuk meningkatkan kesadaran masyarakat sehingga tidak tertarik untuk mengkonsumsi nya lagi, jika tidak ada ketertarikan lagi dari masyarakat untuk mengkonsumsinya otomatis pelaku usaha pun juga berhenti untuk memperdagangkannya, dan produk produk tersebut perlahan - lahan habis di masyarakat.

Namun yang menjadi masalah adalah, sosialisasi ini belum menyeluruh dan rutin dilakukan dan informasi tentang diadakannya sosialisasi juga tidak sepenuhnya diketahui masyarakat ataupun pelaku usaha. Sosialisasi yang biasanya dilakukan per kecamatan tidak bisa rutin dilakukan, menurut keterangan dari perwakilan Balai Besar Pengawas Obat dan Makanan, mereka terkendala di biaya dalam melakukan sosialisasi ini, karena dalam melakukan sosialisasi itu membutuhkan biaya untuk mendanai konsumsi ataupun transport masyarakat termasuk pelaku usaha yang hadir dalam sosialisasi mereka. Dan juga pada sosialisasi yang dilakukan lewat Padang Expo atau Padang Fair juga belum berjalan efektif, dikarenakan sosialisasi yang seperti itu hanya dihadiri oleh orang yang mau melihat saja. Sehingga kemauan di dalam diri pelaku usaha belum 
ada untuk menghadiri sosialisasi yang bersifat seperti itu.

Untuk itu dibutuhkan pendekatan yang pas yang harus dilakukan oleh Balai Besar Pengawas Obat dan Makanan dalam melakukan sosialisasi ke pelaku usaha ini. seperti dengan rutin mendatangi tempat tempat distribusi kosmetik, melakukan sosialisasi secara rutin. Sehingga perlahan lahan tumbuhnya kesadaran pelaku usaha untuk menghentikan penjualan kosmetik ilegal ini.

\section{3) Adaptasi}

Adaptasi merupakan keahlian organisasi supaya bisa menyesuaikan diri dengan lingkungannya. Batasan dari pengertian adaptasi dapat diukur dari bagaimana organisasi melakukan perubahan terhadap situasi lingkungan yang berubah dan proses mengatasi halangan-halangan dari lingkungan tersebut. Untuk melihat proses penyesuaian diri oleh Balai Besar Pengawas Obat dan Makanan Padang, dapat dilihat dari bagaimana kemampuan mereka atau strategi yang dapat mereka lakukan untuk mengatasi peredaran kosmetik di masyarakat, yang mana pada zaman sekarang ini teknologi semakin yang canggih dan tidak menutup kemungkinan kalau kosmetik ilegal tidak hanya diperjual belikan secara langsung tapi juga melalui online.

Untuk menghadapi penjualan kosmetik secara online ini, Balai Besar Pengawas Obat dan Makanan sudah mempunyai strategi yang dinamai dengan Operasi Pangea. Opereasi Pangea adalah untuk mengawasi peredaran kosmetik secara online dengan cara pihak Balai Besar Pengawas Obat dan Makanan membeli kosmetik itu ke salah satu penjual online, setelah itu mereka melakukan uji coba terhadap bahannya. Jika kosmetik tersebut kedapatan mengandung bahan berbahaya, maka akan langsung diumumkan dalam Public Warning BPOM yang bisa diakses melalui web BPOM. BPOM juga menertbitkan Public Warning tersebut dalam bentuk buku, seperti gambar berikut:

\section{Gambar 1. Public Warning yang diterbitkan oleh BPOM}

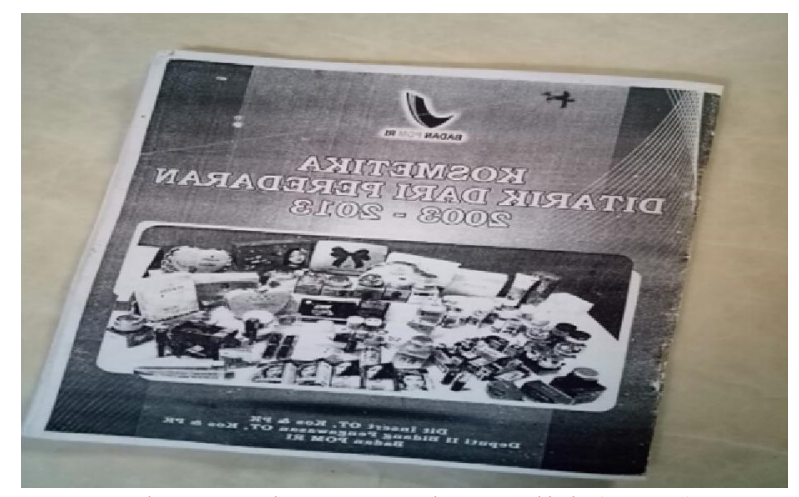

Sumber: Dokumentasi Peneliti (2019)

Namun yang menjadi penghambat efektifnya Balai Besar Pengawas Obat dan Makanan dalam mengawasi produk secara online ini adalah karena tidak semua toko online yang bisa mereka jangkau. Karena perkembangan teknologi yang semakin pesat, penjualan kosmetik secara online pun semakin banyak beredar. Untuk itu dengan telah diterbitkannya Public Warning dari BPOM diharapkan konsumen bisa memilih dengan cerdas mana kosmetik yang baik dikonsumsi, sehingga dapat pula menghambat pelaku usaha kosmetik online untuk memperdagangkannya.

Untuk itu dibutuhkan suatu penertiban yang efektif sehingga dapat memberi efek jera bagi pelaku usaha kosmetik tersebut. Penertiban dapat meningkatkan:

a) Kesadaran Hukum

Untuk dapat menaati suatu peraturan hukum yang telah dibuat diperlukannya kesadaran hukum. Perasaan hukum dan keyakinan hukum seseorang di masyarakat merupakan akar dari kesadaran hukum masyarakat. Kesadaran hukum masyarakat adalah satuan terbanyak dari kesadarankesadaran hukum seseoang mengenai suatu kejadian tertentu. Kesadaran hukum individu dapat diukur dari sebarapa patuh dan mengerti mereka terhadap peraturan perundang-undangan yang berlaku. 
Peredaran kosmetik ilegal juga dapat dikurangi jika individu-individu sudah memiliki kesadaran tentang peraturan hukum yang sudah dibuat dan tidak melanggarnya. Dalam UU Kesehatan nomor 36 tahun 2009 pasal 196 menjelaskan mengenai sanksi hukum yang menjerat pelaku usaha kosmetik jika kedapatan memproduksi atau mengedarkan kosmetik ilegal yaitu hukuman penjara maksimal 15 tahun atau membayar denda sebesar 1,5 milyar rupiah.

Namun pada kenyataannya pelaku usaha yang kedapatan memproduksi dan mengedarkan hanya dijatuhi hukuman berupa wajib lapor dikarenakan masih lemahnya implementasi dari peraturan perundang - undangan ini. Lemahnya implementasi peraturan perundang undangan menyebabkan masih berani pelaku usaha untuk memperdagangkan kosmetik ilegal ini, sehingga peredarannya masih sulit untuk diatasi.

Untuk itu saat ini BPOM sedang berusaha untuk melobi DPR supaya membuat regulasi yang lebih tegas serta menyebabkan efek jera, dan juga diperlukannya sosialisasi tentang peraturan hukum ini yang dilakukan secara terusmenerus. Sehingga diharapkan tumbuhnya kesadaran dan kepatuhan pelaku usaha akan hukum yang ada.

\section{b) Pengendalian social}

Pengendalian sosial yang dilakukan oleh Balai Besar POM di Padang demi mengatasi peredaran kosmetik ilegal ini adalah berupa sosialisasi dan tindakan pembinaan yang sekiranya harus dilakukan untuk menjaga ketertiban umum, baik itu kepada pelaku usaha kosmetik ataupun konsumen kosmetik.

Pengendalian sosial yang dilakukan oleh Balai Besar POM di Padang yaitu berupa sosialisasi yang dilakukan per kecamatan dan sosialisasi yang dilakukan saat adanya Padang Expo ataupun Padang Fair. Kedua, berupa pembinaan yang dilakukan langsung ke pelaku usaha kosmetik saat Balai Besar POM melakukan inspeksi ke tempat tempat distribusi kosmetik. Ketiga, memberikan sanksi atau hukuman bagi pelaku usaha kosmetik yang masih kedapatan memperdagangkan produk produk ilegal tersebut.

Pengendalian sosial itu bisa dikatakan efektif apabila sudah mencapai tujuan nya dan tepat sasaran, yang mana tujuan Balai Besar POM melakukan pengendalian sosial tersebut agar menertibkan pelaku usaha yang masih memperdagangkan kosmetik ilegal, untuk menambah pengetahuan dan kesadaran pelaku usaha dan konsumen mengenai bahaya nya kosmetik ilegal demi terciptanya suasana damai, nyaman, tertib, dan aman bagi masyarakat dalam memilih kosmetik.

Namun yang menjadi masalah adalah pertama, belum menyeluruhnya sosialisasi dilakukan, sehingga informasi mengenai bahaya nya dan seperti apa kosmetik ilegal ini masih minim di dapat. Kedua, belum ada nya sanksi hukum yang tegas dan memiliki efek jera bagi pelaku usaha yang memperdagangkan kosmetik ilegal, sehingga tujuan untuk menciptakan ketertiban umum, meningkatkan kesadaran pengetahuan masyarakat mengenai bahaya nya kosmetik ilegal serta menciptakan suasana yang aman di masyarakat dalam memilih produk kosmetik yang aman tersebut belum tercapai.

Sehingga ini menjadi tugas besar bagi Balai Besar Pengawas Obat dan Makanan untuk mengatasi peredaran kosmetik ilegal ini. Hal yang perlu dilakukan adalah melukan sosialisasi ataupun pembinaan yang rutin dan tepat sasaran sehingga dapat efektifnya pengendalian sosial yang dilakukan tersebut.

\section{Kendala yang dihadapi :}

a) Kendala Internal

1) Kapasitas laboratorium yang belum optimal 
Agar semua kegiatan yang dilakukan dalam laboratorium dapat berjalan dengan lancar maka dibutuhkan SDM yang profesional dan laboratorium yang canggih dengan alat - alat yang optimal. Saat ini kapasitas laboratorium yang dimiliki oleh Balai Besar POM masih belum optimal dengan alat - alat laboratorium yang masih bersifat standar, untuk itu saat ini Balai Besar POM di Padang secara terus menerus dan berkesinambungan terus memperkuat kapabilitas dan profesionalisme SDM maupun sarana dan prasarana laboratorium seperti peralatan laboratorium, pengembangan metoda analisa, reagensia, baku pembanding dan suku cadang, sehingga dapat dengan optimal untuk mengawal semua produk Obat dan Makanan yang beredar di wilayah Propinsi Sumatera Barat.

2) Cakupan pengawasan sarana produksi dan distribusi kosmetik yang belum optimal

Saat ini kosmetik nampaknya sudah menjadi kebutuhan primer manusia, terutama para wanita. Untuk itu semakin banyaknya sarana produksi dan distribusi kosmetik dijumpai saat ini. Saat ini menurut data dari Balai Besar POM di Padang ada sekitar 170 sarana distribusi kosmetik di Sumatera Barat dan sekitar 60 ada di Padang, namun karena untuk menghemat waktu, mereka biasanya hanya memeriksa setengah dari jumlah sarana distribusi kosmetik di Padang tersebut.

Dapat diketahui bahwa Balai Besar POM hanya mengecek sarana - sarana distribusi kosmetik yang biasanya kedapatan memperdagangkan ksometik ilegal, sementara selebihnya tidak mereka cek kerena dianggap aman. Namun juga tidak menutup kemungkinan, kalau sarana distribusi yang awalnya dianggap aman tersebut malah juga ikut memperdagangkan kosmetik ilegal karena meresa tempat mereka lolos dari pengecekan Balai Besar POM.
Untuk itu Mempertimbangkan luas dan kondisi geografis Propinsi Sumatera Barat serta meningkatnya jumlah sarana produksi dan distribusi kosmetik, Balai Besar POM di Padang perlu meningkatkan cakupan Inspeksi agar dapat menjamin bahwa produk kosmetik yang dihasilkan dan diperdagangkan didasarkan kepada kaidah produksi dan distribusi yang baik.

3) Pemberdayaan masyarakat belum optimal

Pembinaan pada produsen yang dilakukan belum optimal, dapat dilihat dari indikator masih tingginya produk kosmetik tanpa izin edar yang beredar, pembinaan terhadap pelaku usaha belum optimal disebabkan karena pembinaan yang dilakukan belum tepat sasaran, artinya masih banyak produsen yang menghasilan produk tanpa izin edar, belum menjadi sasaran dalam penyebaran informasi/penyuluhan.

4) Penegakan hukum di bidang obat dan makanan belum menimbulkan efek jera

Selama ini upaya penegakan hukum yang dilakukan dinilai belum efektif. Rendahnya putusan pengadilan yang dijatuhkan kepada pelanggar hukum tindak pidana bidang Obat dan Makanan merupakan salah satu penyebab tidak efektifnya upaya penegakan hukum. Belum adanya Peraturan perundang- undangan khusus tentang pengawasan obat dan makanan yang dapat memberikan sangsi yang berat sehingga memberi efek jera terhadap pelaku tindak pidana.

Pemerintah benar - benar perlu membuat regulasi yang baru, yang dapat memberikan efek jera bagi pelaku pengedaran atau yang memperoduksi kosmetik ilegal. Sehingga peredarannya dapat dikurangi atau lebih bagusnya dapat benar - benar habis dimasyarakat.

b) Kendala Eksternal

1) Teknologi yang semakin berkembang 
Dengan teknologi informasi yang semakin canggih dan berkembang saat ini tidak menutup kemungkinan bahwa perdagangan kosmetik semakin bebas sekarang ini. Misalnya melalui online, yang mana penjualan kosmetik bisa dijumpai di Instagram, Twitter atau Facebook. Hal tersebut menuntut peningkatan peran dan kapasitas instansi Balai Besar POM dalam mengawasi peredaran kosmetik atau pun peredaran produk-produk lain.

Walaupun Balai Besar POM di Padang sudah mempunyai strategi untuk menghadapi penjualan online ini, yang dinamai dengan Operasi Pangea, namun hal tersebut masih belum bisa menghentikan penjualan kosmetik secara online tersebut, dikarenakan karena keterbatan kemampuan Balai Besar POM untuk mengetahui penyebaran toko - toko online ini, sehingga memberi peluang tidak terawasinya produk yang beresiko terhadap kesehatan.

2) Perilaku masyarakat yang ingin tampil secara instant

Masih beredarnya kosmetik ilegal hingga saat ini dikarenakan karna masih adanya permintaan dari masyarakat akan barang tersebut. Dengan berbagai macam alasan seperti ingin tampil cantik dengan cepat, ingin dapat kulit yang putih dengan cepat ataupun karena ikut-ikut teman.

Untuk itu diperlukan upaya yang optimal dari Balai Besar POM untuk menanganinya, seperti gencar melakukan penertiban, ataupun melakukan sosialisasi terus menerus sehingga tumbuhnya kesadaran masyarakat untuk menghentikan pemakaian produk ilegal ini dan pelaku usaha pun ikut berhenti memperjual belikannya.

3) Ketidakjujuran pelaku usaha saat dilakukannya penertiban

Saat Balai Besar POM melakukan penertiban kosmetik ilegal ke tempattempat distribusi kosmetik, mereka menemukan kendala seperti tidak jujur nya pelaku usaha yang memasarkan kosmetik saat mereka melakukan pengecekan.
Misalnya saat Balai Besar POM melakukan pengecekan ke tempat distribusi kosmetik, pelaku usaha disana mengatakan bahwa boss nya sedang tidak di tempat oleh karena itu tidak bisa melakukan pengecekan gudang, dan juga karena adanya kesolidaritasan antar sesama pelaku usaha ini.

Jadi saat Balai Besar POM melakukan pengeceka ke satu tempat distribusi kosmetik, pelaku usaha ini memberi tahu pelaku usaha yang lain bahwa sedang adanya pengecekan kosmetik sehingga jika ada pelaku usaha yang masih memperjual belikan kosmetik ilegal mereka langsung menyembunyikannya supaya tidak disita pihak Balai Besar POM.

Upaya yang dilakukan :

1) Upaya Pre-emtif. Upaya pre-emtif yang dilakukan Balai Besar Pengawas Obat dan Makanan di Padang untuk meningkatkan efektivitas dalam penertiban pelaku usaha yang masih memperdagangkan kosmetik ilegal adalah dengan rutin melakukan sosialisasi dan memperkuat layanan informasi masyarakat melalui media cetak, media elektronik, iklan, brosur, baliho ataupun media sosial lainnnya yang bertujuan untuk menambah pengetahuan dan kesadaran tentang bahaya nya kosmetik ilegal ini.

2) Upaya Preventif. Upaya preventif yang dilakukan Balai Besar Pengawas Obat dan Makanan adalah melakukan razia dan inspeksi secara rutin ke tempat tempat yang dianggap rawan menjadi lokasi perdagangan kosmetik ilegal sehingga keberadaannya dapat benar benar dihilangkan dari masyarakat.

3) Upaya Represif. Upaya represif yang dilakukan adalah saat ini BPOM tengah berupaya untuk melobi DPR supaya membuat regulasi yang baru mengenai sanksi hukum yang dapat benar - benar menimbulkan efek jera bagi pelaku yang memproduksi ataupun yang mengedarkan kosmetik ilegal, sehingga 
tidak ada lagi pelaku yang hanya diberi sanksi wajib lapor.

Balai Besar POM belum cukup efektif dalam melakukan penertiban pelaku usaha kosmetik ilegal, yang mana menurut Duncan (Steers, 1985) efektif nya suatu organisasi dapat dilihat efektifnya pencapaian tujuan, integrasi yang dilakukan dengan baik dan kemampuan adaptasi organisasi tersebut. Pertama, tujuan dari penertiban kosmetik ilegal belum sepenuh nya tercapai dikarenakan beberapa faktor yaitu, kurangnya kepedulian masyarakat terhadap kosmetik ilegal dan karena masih ada minat mereka mengkonsumsi kosmetik tersebut. Kedua, integrasi yang berupa sosialisasi yang dilakukan ke masyarakat belum sepenuhnya optimal dikarenakan kurangnya anggaran sehingga sosialisasi ini tidak bisa rutin dilakukan dan juga karena kurangnya informasi yang didapatkan masyarakat mengenai jalannya sosialisasi ini. Ketiga, dalam menghadapi perkembangan teknologi yang semakin canggih, BBPOM sudah dapat beradaptasi dengan baik yaitu dengan adanya Operasi Pangea BBPOM bisa mengawasi penjualan kosmetik secara online.

Menurut Soekanto (2012) penertiban dapat meningkatkan kesadaran hukum dan pengendalian sosial. Namun hal tersebut tidak sesuai dengan kenyataan yang ada dilapangan, yang mana dari penertiban yang dilakukan oleh BBPOM belum menyebabkan tumbuhnya kesadaran hukum bagi pelaku usaha kosmetik ilegal. Dikarenakan masih lemahnya implementasi UU Nomor 36 tahun 2009 Tentang Kesehatan, yang mana kebanyakan kasus kosmetik ilegal pelaku nya hanya dikenai hukuman berupa wajib lapor. Dibutuhkan kebijaksanaan dari pemerintah untuk menciptakan peraturan hukum yang lebih tegas (Frinaldi, 2017). Sehingga dengan adanya peraturan hukum yang dapat menimbulkan efek jera, diharapkan tumbuhnya kesadaran pelaku usaha terhadap hukum yang ada.
Selanjutnya menurut Soekanto (2012) pengendalian sosial dapat dikatakan efektif apabila telah mencapai tujuan dan sasarannya. Namun pengendalian sosial yang dilakukan oleh BBPOM belum cukup efektif dikarenakan belum menyeluruhnya sosialisasi dilakukan sehingga tujuan untuk menyebarkan informasi mengenai bahanyanya kosmetik ilegal ini belum optimal dilakukan.

Terbatasnya anggaran dan SDM di Balai Besar POM Padang menjadi faktor penghambat dalam melaksanakan kegiatankegiatan yang berkaitan dengan penertiban. Selain itu karena teknologi yang semakin canggih menyebabkan kosmetik ilegal semakin cepat dan luas beredar di masyarakat.

Sesuai dengan teori yang dikemukan oleh Nawawi (2010) dibutuhkan upayaupaya untuk meningkatkan penertiban ini. Pertama upaya pre-emtif, menanamkan norma-norma dan nilai-nilai di dalam diri pelaku usaha kosmetik tentang bahaya nya pemakaian dari kosmetik ilegal tersebut. Kedua, upaya preventif dengan gencar melakukan penertiban ke tempat-tempat yang dianggap rawan dalam beredarnya kosmetik ilegal. Ketiga upaya represif, dengan menjatuhi hukuman yang dapat menimbulkan efek jera kepada pelaku usaha kosmetik ilegal sehingga mereka tidak memperdagangkan produk-produk ilegal lagi.

\section{PENUTUP}

Berdasarkan hasil temuan penelitian yang telah dilakukan oleh peneliti tentang Efektivitas Pengawasan dan Penertiban Balai Besar Pengawas Obat dan Makanan terhadap Kosmetik Ilegal dan Berbahaya di Kota Padang, maka dapat ditarik kesimpulan yaitu pertama, pencapaian tujuan Balai Besar POM untuk mengurangi peredaran kosmetik ilegal di masyarakat belum sepenuhnya terpenuhi, dikarenakan karena belum tumbuhnya kesadaran masyarakat untuk menghentikan pemakaian 
produk tersebut, otomatis pelaku usaha pun juga belum berhenti untuk menjualnya.

Kedua, integrasi, sosialisasi yang dilakukan Balai Besar POM masih belum efektif dikarenakan karena keterbatasan waktu, kurangnya anggaran dan belum menyeluruhnya sosialisasi dilakukan.

Ketiga, adaptasi, dalam menghadapi perkembangan teknologi di zaman sekarang ini, yang mana dengan itu makin banyaknya kosmetik yang beredar secara online. Untuk itu Balai Besar POM sudah mempunyai strategi yang dinamai dengan Operasi Pangea. Namun strategi ini belum sepenuhnya efektif dikarenakan karena tidak semua yang online bisa terawasi, sehingga masih ditemukannya kosmetik ilega yang dijual secara online.

Sehingga diperlukannya suatu penertiban yang efektif yang dapat meningkatkan kesadaran hukum dan pengendalian sosial. Namun yang terjadi adalah belum tumbuhnya kesadaran dan kepatuhan pelaku usaha terhadap hukum yang ada, karena masih lemahnya implementasi UU Nomor 36 tahun 2009 Tentang Kesehatan. Dan juga pengendalian sosial yang dilakukan belum mencapai tujuan dan sasaran yang tepat.

Pihak Balai Besar Pengawas Obat dan Makanan harus lebih gencar lagi melakukan sosialisasi untuk membentuk kesadaran pelaku usaha atas hukum yang ada, harus lebih gencar lagi melakukan pembinaan yang tepat sasarn kepada pelaku usaha kosmetik supaya tidak ada lagi pelaku usaha yang menyimpang atau yang melanggar dengan masih memperdagangkan kosmetik ilegal tersebut.

\section{DAFTAR KEPUSTAKAAN}

Frinaldi, A. (2017). The Use of Freies Ermessen (Discretion) in the Activity of Central Government and Local Government. Jurnal Ilmu Hukum Universitas Muhammadiyah Metro.
Frinaldi, A. (2019). Policy Management to Develop Tourism Work Culture Consciousness and Increasing Visiting People's Satisfaction. Jurnal Studi Pemerintah, 10.

Larasati, S. P., \& Haksama, S. (2016). Penerapan Theory of Constraint pada Kepuasan Kerja Karyawan Rumah Sakit Mata Undaan Surabaya. Jurnal Administrasi Kesehatan Indonesia, 4(2), 155. https://doi.org/10.20473/jaki.v4i2.201 6.155-162.

Nawawi, B. (2010). Kebijakan Legislatif Dalam Penanggulangan Kejahatan dengan Pidana Penjara. yogyakarta: genta publishing.

Soekanto, S. (2012). pokok-pokok sosiologi hukum. jakarta: rajawali pers.

Steers, R. (1985). efektivitas organisasi. jakarta: erlangga.

Witya, T., \& Frinaldi, A. (2019). Efektivitas Implementasi E-Government Dalam Pelayanan Kependudukan di Dinas Kependudukan dan Pencatatan Sipil Kota Padang. Journal Of Multidisciplinary Reserch and Development, 1(3), 428.

Peraturan Per UU Nomor 36 tahun 2009 tentang Kesehatan.

Keputusan Kepala Badan Pengawas Obat dan Makanan Republik Indonesia No. HK.00.05.4.1745 Tentang Kosmetik.

Peraturan Pemerintah Nomor 32 Tahun 2004 tentang Pedoman Polisi Pamong Praja. 